UDC 663.1:663.5

\title{
ETHANOL PRODUCTION FROM COCOYAM (Xanthosoma sagittifolium): APPLICATION OF THERMODYNAMIC-TOPOLOGICAL ANALYSIS
}

\author{
S. Serna-Loaiza1 ${ }^{1}$ Yu.A. Pisarenko² ${ }^{2}$ C.A. Cardona ${ }^{1, @}$ \\ ${ }^{1}$ Institute of Biotechnology and Agroindustry, National University of Colombia, headquarters \\ Manizales, Manizales-Caldas, Colombia \\ ${ }^{2}$ Moscow Technological University (M.V. Lomonosov Institute of Fine Chemical Technologies), \\ Moscow 119571 , Russia \\ @Corresponding author e-mail: ccardonaal@unal.edu.co
}

\begin{abstract}
Cocoyam (Xanthosoma sagittifolium (L.) Schott) is a tropical plant of the family of Araceas. Nigeria, China and Ghana are the countries that currently own most of the world production of this plant. In Colombia, there are not extensive crops of this plant, but it is used for animal feeding mainly. The plant has an aerial part with a high content of protein (leaves) and a tuber with an average starch content about $25 \% \mathrm{w} / \mathrm{w}$. Compared to others starchy raw materials, this is a high value. Due to this fact this first-generation starchy material could be considered as a possible feedstock for the production of ethanol. Process design must ensure that the most advanced concepts are applied at the design and processing stage for every raw material to ensure efficient and more sustainable processes. For this reason, thermodynamic-topological analysis was used for the design of the stage of the produced ethanol purification. This work presents the process of ethanol production using cocoyam tuber. The software Aspen Plus v8.6 (Aspen Technology, Inc., USA) was used for the techno-economic assessment, and the Waste Reduction Algorithm (WAR) of the Environmental Protection Agency of the EE.UU. (EPA) was used to measure the environmental performance. The obtained production cost was 1,6 USD per kilogram, and the environmental impact was very low. This is an excellent incentive to promote the application of this feedstock to obtain a feasible alternative for the production of ethanol. Additionally, the use of thermodynamic-topological analysis in the design stage of the purification stage of the process proved to be very useful and easily applied.
\end{abstract}

Keywords: bioethanol, cocoyam, food security, techno-economic assessment, thermodynamictopological analysis, environmental assessment.

\section{ПРОИЗВОДСТВО ЭТАНОЛА ИЗ КОЛОКАЗИИ (Xanthosoma sagittifolium): ПРИМЕНЕНИЕ ТЕРМОДИНАМИКО-ТОПОЛОГИЧЕСКОГО АНАЛИЗА}

\section{С. Серна-Аоаиза ${ }^{1}$ Ю.А. Писаренко ${ }^{2}$, К.А. Кардона ${ }^{1, @}$}

${ }^{1}$ Наииональный университет Колумбии (Институт биотехнологии и агропромышленности), Манизалес-Кальдас, Колумбия

${ }^{2}$ Московский технологический университет (Институт тонких химических технологий имени М.В. Аомоносова), Москва 119571, Россия

@Aвтор для переписки, e-mail: ccardonaal@unal.edu.co

Колоказия (Xanthosoma sagittifolium (L.) Schott) является тропическим растением семейства Araceas. Нигерия, Китай и Гана представляют собой страны, которые в настоящее время являются лидерами мирового производства этого растения. Колумбия не культивирует колоказию в промышленных масштабах, внутри страны данное растение применяют главнъи образом в качестве корма для животных. Растение имеет надземную часть с высоким содержанием белка в листьях, при этом содержание крахмала в клубнях составляет в среднем около 25\% мас. По сравнению с другим сырьем колоказия содержит крахмала намного 
больше, что позволяет рассматривать ее как первоочередного кандидата в качестве сырья для промышленного производства этанола. При проектировании промышленного проиесса следует учесть наиболее передовые технологические решения, которые позволят увеличить его эффективность и устойчивость. По этой причине на этапе разработки стадии очистки этанола использован термодинамико-топологический анализ. В статье представлен технологический проиесс производства этанола с использованием клубней колоказии в качестве сырья. Технико-экономическая оиенка проиесса и измерение его экологических характеристик проведено с использованием современного програмлного обеспечения: Aspen Plus v8.6 (Aspen Technology, Inc., США) и Алгоритма сокрашения отходов (WAR) Агентства по охране окружаюшей средъ ЕE.UU. (ЕРA). Стоимость производства этанола составила 1,6 долл. США за килограмм при низком воздействии на окружаюшую среду. Это отличный стимул для продвижения данного вида сырья в качестве приемлемой альтернативы при произодстве этанола. Использование термодинамико-топологического анализа на стадии проектирования этапа очистки проиесса оказалось простьим очень полезньи средством.

Ключевые слова: Биоэтанол, Колоказия, продовольственная безопасность, технико-экономическая оценка, термодинамико-топологический анализ, экологическая оиенка.

\section{Introduction}

Cocoyam (Xanthosoma sagittifolium (L.) Schott) is a plant typically grown in tropical climates, whose origin is Central America [1]. In the world, the regions with the highest productions and crop areas of this plant are mainly located in West Africa (Nigeria and Ghana), Asia (China) and Oceania [2, 3]. In Colombia, this plant does not have large crop areas, and the uses are mostly directed to feeding (200 tonnes per year directed for this use). Just a small portion of the production is directed to human food, sales and agroindustry (20 tonnes per year) [4]. However, the leaves and the stem of the plant are the most used parts, while the tuber is generally discarded. This tuber has around 15 and 39 percent of carbohydrates, 2-3 percent of protein and 70-77 percent of water. This composition gives great potential to these roots, as they can be used to obtain starches or starch-based compounds (glucose, plasticizers, etc.) as value added product [5]. The average starch content of cocoyam is about $25 \% \mathrm{w} / \mathrm{w}$ [1], which is a high value compared to other starchy feedstocks as potatoes (15\%) [6] and yucca (18\%) [7].

Regarding ethanol, the progressive depletion of energy resources which are mainly based on nonrenewable fuels and the changes that the world is facing and the atmospheric pollution as consequences of the combustion of oil-derived fuels has directed the research aim into renewable sources of energy [8]. Colombian government has defined the use of bioethanol as a gasoline enhancer to reduce greenhouse gases, gasoline imports, and to boost the rural economy [9]. Ethanol is emerging as one of the most promising alternate energy sources due to its clean burning nature and no detectable emissions of pollutant gases as $\mathrm{CO}$ or NOx [10]. Ethanol can be produced from lignocellulose- and starch-derived glucose. For starch-derived glucose, one of the most crucial problems is the competition for natural and agricultural resources with food and food-related use and threatening food security [11].
Some experimental work was undertaken to assess the potential of cocoyam. The initial step was the obtainment of starch and enzymatic hydrolysis to convert the starch into sugars [12]. The experimental data obtained, process conditions and fermentation yield were used to simulate the production process with the software Aspen Plus (Aspen Technology, USA), and the economic package of the software was used for the economic assessment. The environmental assessment of the process was carried out using the software WAR GUI (Chemical Process Simulation for Waste Reduction) [13].

Referring to process design and biomass utilization, specifically for Colombian biomass, regardless of the production scale, the most important aspect is to ensure two concepts. The first concept is that biomass must be cheap, available and accessible. The second concept is that the process must be as efficient as possible, especially because Colombia cannot focus only on determining which raw materials are available to convert into a given product. The focus must ensure that the most advanced concepts are applied at the design and processing stage to every raw material to ensure efficient processes that direct to more sustainable processes. For this reason, thermodynamic-topological analysis was used for the design of the purification stage of the produced ethanol.

The obtained yields in the experimental stage and the results of the techno-economic and environmental assessment showed that cocoyam can be a feasible feedstock for ethanol production. Compared to other starchy feedstocks, cocoyam is not used as human food; hence, the proposed process will not threat food security [14-16].

\section{Methodology}

\subsection{Experimental}

\subsubsection{Cocoyam obtainment}

Previous to the simple collection process and in order to identify the correct plant to be collected, it was necessary to do a disambiguation between two 
species that are known in Colombia as "cocoyam". It is important to clarify that this differentiation is done considering that the consulted literature recognizes as cocoyam: Xanthosoma sagittifolium [17] and Alocasia macrorrhiza [18]. It was determined that the specie Xanthosoma sagittifolium corresponds to the plant found in Colombia, and hence the collection was performed.

\subsubsection{Starch content determination}

The quantitative determination was performed following the sulfuric acid-phenol method [19, 20]. This method has two stages. The first one consisted in the conversion of starch to hydroxymethyl furfural (HMF) in an acidic medium. The second stage is the reaction of HMF with phenol producing a green solution with a maximum absorbance at $490 \mathrm{~nm}$. The concentration of starch is determined with a pattern curve in a spectrophotometer.

\subsubsection{Starch enzymatic hydrolysis}

The selected starch samples were used to obtain a sugar-rich mixture. Hence, enzymatic hydrolysis was performed using $\alpha$-amylase (Liquozyme L $240 \mathrm{KNU} / \mathrm{g}$ Novozyme ${ }^{\circledR}$ ) and amyloglucosidase (Spirizyme Fuel 750 AUG/g Novozyme®) enzymes. The sample was solubilized with water to a concentration of 67 grams per liter. This solution was gelatinized at $71^{\circ} \mathrm{C}$ for 30 minutes in order to solubilize the starch. The primary and secondary enzymatic liquefactions were performed. Both enzymes were used at their maximum load (0.01$0.2 \% \mathrm{w} / \mathrm{w}$ for Liquozyme $\mathrm{L}$ and $0.046-0.066 \% \mathrm{w} / \mathrm{w}$ for Spirizyme Fuel) [21].

\subsubsection{Ethanol fermentation and product characterization}

Ethanol was produced via fermentation with Saccharomyces cerevisiae at $32^{\circ} \mathrm{C}$ with a fermentation volume of $60 \mathrm{~mL}$. The $\mathrm{pH}$ was between 3.8 and 4.5, and the fermentation was carried out for 48 hours. Glucose and ethanol were quantified using High Performance Liquid Chromatography (HPLC) LC2010 Shimadzu.

\subsection{Application of thermodynamic-topological analysis}

The analysis of the statics and hence the application of thermodynamic-topological analysis in the distillation allows selecting the limiting stable states, which represent the maximum conversion and selectivity [22]. This methodology can be applied for different distillation schemes such as conventional distillation, distillation trains with pressure swing, azeotropic distillation, extractive distillation, reactive distillation, distillation with pervaporation and reactive extraction [23]. It has been specially applied to reactive distillation, because the main advantage of simultaneous reaction-separation processes is the possibility of increasing the reaction rate and delaying the generation of undesired products [24].

The application of thermodynamic-topological analysis consists in the application of a series of steps, in which the thermodynamic behavior of the mixture is visualized using ternary or quaternary diagrams. In general terms, it consists first in determining the boiling points of the compounds, selecting a thermodynamic model that describes correctly the vapor and liquid phases of the mixture, identifying the presence of azeotropes and liquid-liquid equilibria, graphing the ternary/quaternary diagrams and locating the respective azeotropes and liquid-liquid equilibria if any. Then, the separation regions (or concentration simplex) are identified with the residue curves and the distillation trajectories. Finally, once this graph is built, it is possible to establish the possible separation scheme, the composition of the phases that are separated and so on. Now, these steps will be developed in the following sections.

\subsection{Simulation procedure}

The objective of the simulation is to generate the mass and energy balances of the process. With this information, it is possible to calculate the requirements of raw materials, utilities and energy. The main simulation tool used is the commercial software Aspen Plus (Aspen Technology, Inc., EE.UU.). For the description of the properties and behavior of the compounds, it was chosen to use an activity coefficients model (Non-Random TwoLiquid (NRTL)) to describe the liquid phase and an equation of state (Hayden-O'Conell) for the vapor phase.

\subsection{Process description}

The production of ethanol using cocoyam tuber can be described as a five-stage process: raw material pretreatment, hydrolysis, fermentation, separation and dehydration. The process flow diagram is shown in Figure 1. In the pretreatment and hydrolysis section the tuber is converted into fermentable sugars. Considering the high concentration of glucose in the substrate stream and the achieved experimental yields, the concentration of ethanol in the fermentation exceeded the product inhibition limit of the microorganism $(11-12 \% \mathrm{v} / \mathrm{v}$ of ethanol) $[25,26]$. To avoid this inhibition, extractive fermentation using n-dodecanol as a solvent is proposed based on the research previously done by Gutierrez et al. [27]. The fermentation broth is mixed with $n$-dodecanol. Then, after filtering the biomass, the outlet stream enters into a decanter, in which the organic phase has a higher concentration of ethanol. The organic phase enters into an evaporator to recover the solvent, which is recycled. The aqueous phase enters the purification step in a distillation column, in which ethanol is concentrated up to $50 \%$ 
wt. Then, the distillate is mixed with the organic phase and enters the rectification column, in which ethanol is concentrated approximately to the azeotropic point (close to $96 \%$ wt). Finally, ethanol is dehydrated until $99.6 \% \mathrm{wt}$ in a molecular sieve. The process flow diagram for the process described above is shown in Figure 1.

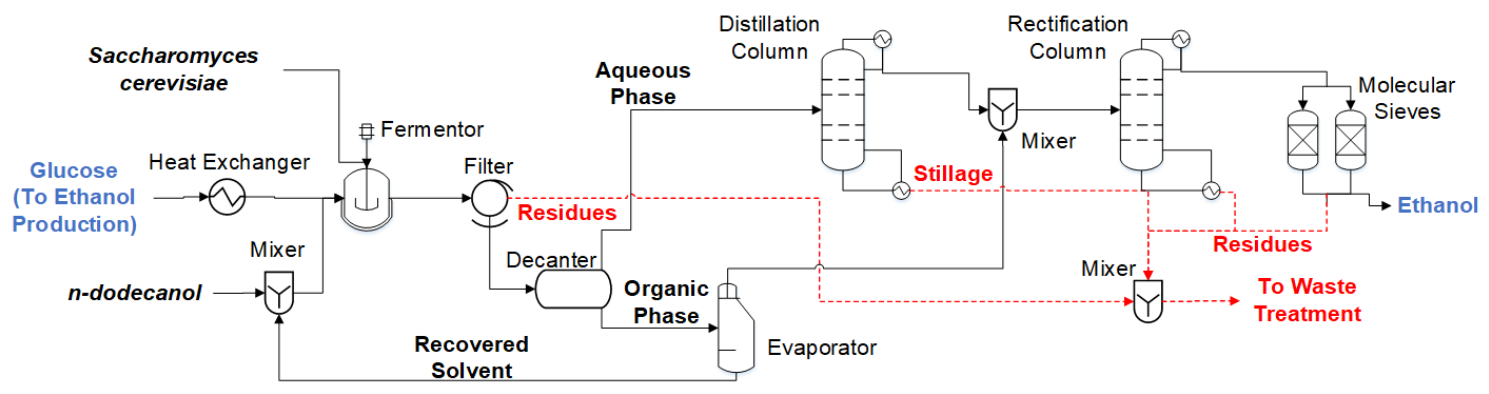

Fig. 1. Process flow diagram of the stage for the production of ethanol.

In the reaction section ethanolic fermentation with Saccharomyces cerevisiae takes place, and in separation and dehydration stages the ethanol is purified. Initially, the cocoyam is taken to a mill crusher, and then it is mixed with water for the gelatinization process, which is performed at $85^{\circ} \mathrm{C}$. Then enzymatic hydrolysis is performed (primary and secondary liquefaction) at $70^{\circ} \mathrm{C}$, and solids are separated using a rotatory drum filter. After this stage a sugar reach stream is obtained.

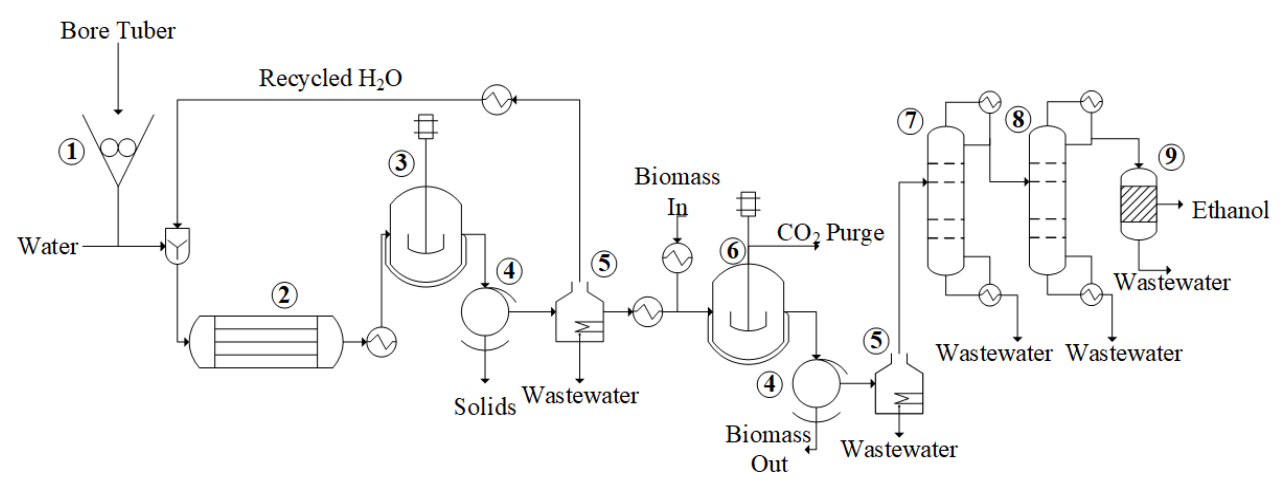

Fig. 2. Process flow diagram of the production of ethanol using cocoyam tuber as raw material:

1 - crusher mill, 2 - gelatinization, 3 - enzymatic hydrolysis, 4 - rotary drum filter, 5 - evaporator, 6 - fermentation, 7 - distillation column, 8 - rectification column, 9 - molecular sieve.

Most part of the water is evaporated and recirculated to the solubilization stage. Then, this stream is fed to a reactor with the biomass in order to produce the ethanol via ethanolic fermentation with $S$. cerevisiae at $30^{\circ} \mathrm{C}$. In the separation and dehydration stage the ethanol is first passed through a distillation column, in which it is purified approximately to $60 \% \mathrm{w} / \mathrm{w}$, then the rectification column purifies the ethanol up to the azeotropic composition, which is approximately $95 \% \mathrm{w} / \mathrm{w}$, and a $4 \mathrm{~A}$ molecular sieve with pore size of $4 \AA$ purifies the ethanol up to $99.6 \% \mathrm{w} / \mathrm{w}$.

\subsection{Economic assessment}

Capital and operation costs were calculated using the Aspen Process Economic Analyzer v8.2 (Aspen Technologies, Inc., EE.UU.) [28]. Specific parameters such as raw materials cost, internal revenue rate $(33 \%)$, annual interest rate $(17 \%)$, working salaries, among others, regarding the Colombian economic conditions, were incorporated in the simulation in order to calculate the unitary production of the ethanol $[29,30]$. This analysis is calculated in USD for a period of 10 years. Capital depreciation is calculated using the straight-line method. Based on the obtained results, corresponding cash flows are generated and the profitability analysis is performed. Additionally, it is possible to generate reports of the associated costs of the project and design details [31]. Table 1 presents the raw materials and utilities costs used in the economic assessment.

\subsection{Environmental assessment}

The Waste Reduction Algorithm of the Environmental Protection Agency of the EE.UU. (EPA) was used as the method to calculate the environmental impact potential (PEI). The PEI for a given amount of mass or energy can be defined as the effect that such element has over the environment as if there were an arbitrary discharge $[33,34]$. The environmental 
Table 1. Raw materials and utilities costs used in the economic assessment

\begin{tabular}{l|c|c}
\hline \multicolumn{1}{c|}{ Item } & Unit & Price \\
\hline Cocoyam $^{\mathrm{a}}$ & $\mathrm{USD} / \mathrm{kg}$ & 0.11 \\
\hline Water $^{\mathrm{b}}$ & $\mathrm{USD} / \mathrm{m} 3$ & 0.74 \\
\hline Electricity $^{\mathrm{b}}$ & $\mathrm{USD} / \mathrm{kWh}$ & 0.14 \\
\hline Fuel $^{\mathrm{c}}$ & $\mathrm{USD} / \mathrm{MW}$ & 24.58 \\
\hline Operator work $^{\mathrm{d}}$ & $\mathrm{USD} / \mathrm{h}$ & 2.56 \\
\hline Supervisor work $^{\mathrm{d}}$ & $\mathrm{USD} / \mathrm{h}$ & 5.12 \\
\hline
\end{tabular}

The cost of the cocoyam was previously calculated considering aspects such as land costs, work force costs, tools, fertilizers, required working periods for soil adaptation, among others.

bPrices taken from the public enterprises that manage such services.

'Estimated cost of gas for a period of 2015-2035 [32].

dPrices taken from the Ministry of Work.

impact cannot be directly measured; however, it can be calculated from different measurable indexes. The WAR GUI software incorporates eight categories: human toxicity per ingestion (HTPI), human toxicity per dermal exposition or inhaling (HTPE), terrestrial toxicity potential (TTP), aquatic toxicity potential (ATP), global

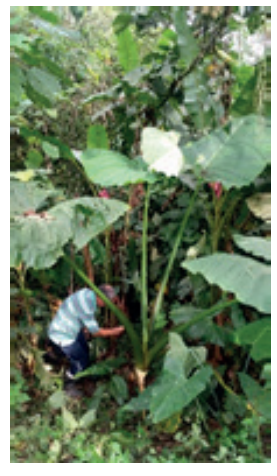

a

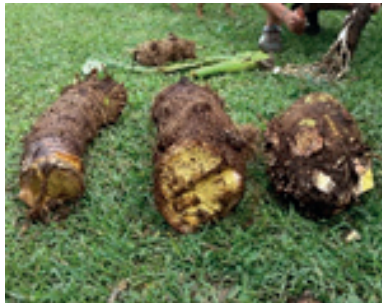

b

warming potential (GWP), ozone depletion potential (ODP), photochemical oxidation potential (PCOP) and acidification potential (AP). This tool considers the impact per mass flows and the impact due to energy requirements of a process based on Aspen Plus generated mass and energy balances. Therefore, the weighed sum of all the impacts determines the final impact per kilogram of product $[35,36]$.

\section{Results and Discussion}

\subsection{Experimental}

\subsubsection{Cocoyam obtainment}

The cocoyam was collected in the rural zone of Manizales at $4^{\circ} 58^{\prime}$ North, $75^{\circ} 39^{\prime}$ 'West in a zone at approximately 1970 meters over sea level, $18{ }^{\circ} \mathrm{C}$ and air humidity between $80-90 \%$. The plants were found in places with abundant vegetation and near water effluents (Figure 3). After the recollection, it was necessary to wash and peel the tuber in order to remove all the dirt and the husk. Then the samples were wet grinded, and the resulting mass was immediately used. The remaining material was frozen and stored at $-20^{\circ} \mathrm{C}$.

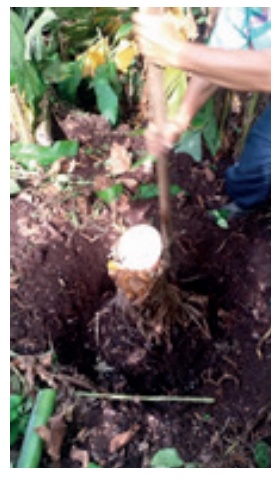

c

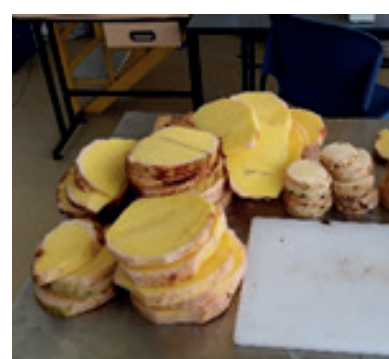

d

Fig. 3. Collected samples of cocoyam plant: (a) Plant; (b) Part of the stem (left) and tuber (right); (c) Underground tuber; (d) Washed and peeled tuber.

\subsubsection{Starch content determination}

Based on the aforementioned procedure, the starch content of the tuber was determined. The assays were performed by triplicate. The obtained value was $0.22 \pm 0.017$ grams of starch per gram of sample. This value is considerably similar to the one reported in literature $(0.25)$. This information is very significant given that these plants are a potential source of starchy raw material for the obtainment of fermentable sugars. However, further analysis regarding the composition of these parts of the plant is necessary, because as the tuber becomes stem, the starch content decreases, and lignocellulosic content increases, hence requiring different processes and approaches that the one of this research.

\subsubsection{Starch enzymatic hydrolysis}

Considering that the only certain sample that had its major content of starch was the one directly taken from the tuber, it was the only one taken to the enzymatic hydrolysis stage. As it was previously mentioned, current use of cocoyam is not directed to the obtainment of fermentable sugars, hence there was no reported yields in literature to compare with obtained results. Due to this, a sample of a common starchy tuber (yucca - Manihot esculenta) was also hydrolyzed. The determination of the obtained sugar was performed with the procedure described in section 2.1.4. Table 2 shows the obtained results.

These results corroborate the potential that cocoyam has for the obtainment of fermentable sugars, compared to other common starchy tubers as yucca. 
Table 2. Obtained yields for enzymatic hydrolysis

\begin{tabular}{l|c|c}
\hline \multicolumn{1}{c|}{ Sample } & $\begin{array}{c}\text { Glucose } \\
\text { concentration }[\mathrm{g} / \mathbf{L}]\end{array}$ & $\begin{array}{c}\text { Obtained yield } \\
\text { [g Glucose/g Sample] }\end{array}$ \\
\hline Cocoyam & $19.24 \pm 0.53$ & 0.282 \\
\hline Yucca & 23.76 & 0.335 \\
\hline
\end{tabular}

\subsection{Application of thermodynamic-topological analysis}

The following step is to perform and analyze the equilibrium diagrams for the ternary mixtures. The ternary diagram is focused on showing the presence of liquid-liquid equilibrium and ternary azeotropes, if any. Figure 4 shows the respective ternary diagrams, and there are no ternary azeotropes in any of the cases. The liquid-liquid dome in both cases has a very favorable tendency, and it is very close to the right side of the triangle, implicating that the concentration of water is very high, without further presence of the solvent.

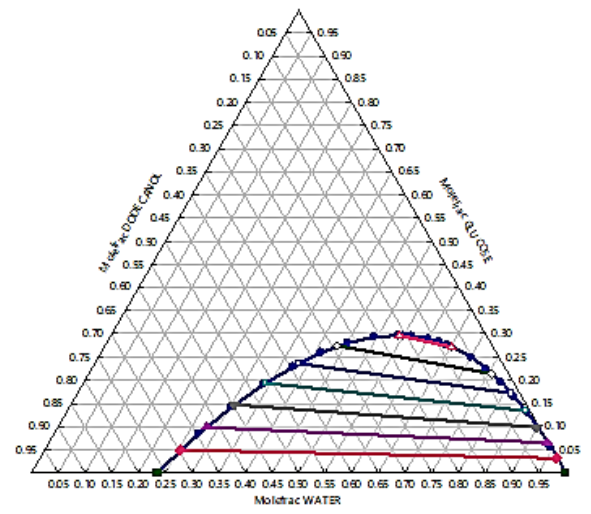

(a) Water-Glucose - Dodecanol
The next step is to graph the residue curves map for each of the ternary mixtures. A residue curve shows the change in the composition of a mixture during continuous evaporation at the vapor-liquid equilibrium. Figure 5 shows the residue curves for the water-ethanol-dodecanol mixture. The residue curves start from the water-ethanol binary azeotrope (minimum temperature azeotrope). The intermediate boiling components in this case are the water and the ethanol, and the high boiling component is the dodecanol. This behavior implies that it is possible to obtain the dodecanol pure, but the water and the ethanol require a type of process different to conventional evaporation methods (as distillation) to obtain them pure. In this specific case, there is only one concentration region corresponding to all the interior of the triangle. This is because all the residue curves have the same tendency, the same low boiling compound and high boiling compound.

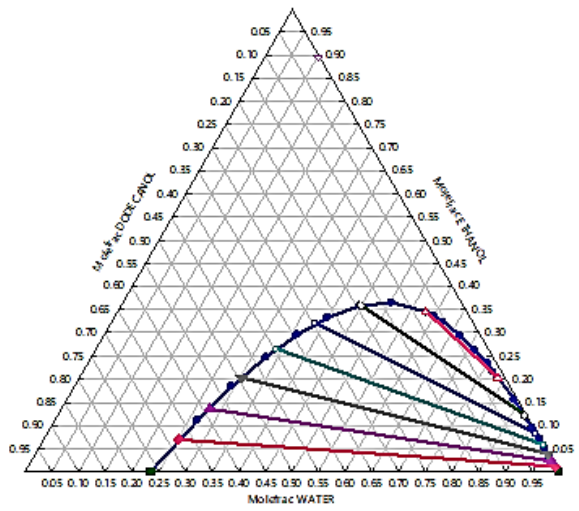

(b) Water - Dodecanol - Ethanol

Fig. 4. Ternary diagrams of the main components at $1 \mathrm{~atm}$

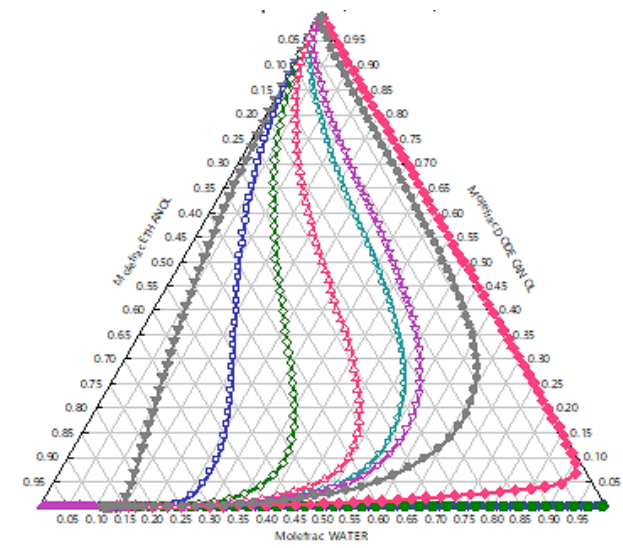

Water - Ethanol - Dodecanol

Fig. 5. Residue curves map for the main components at $1 \mathrm{~atm}$.

After performing all the previous analysis, the next step is to apply specifically the thermodynamictopological analysis to the chosen equipment to determine certain design variables. This application will be performed in the following sections to the extractive fermentation and the distillation and rectification columns.

\subsubsection{Extractive fermentation}

Based on the previous analysis, it is now possible to apply the thermodynamic-topological analysis to determine certain specific variables of each process. The most important variable to be determined for this stage is the required amount of solvent. For this, it is necessary to determine the operation range, which is limited in this case by two conditions: the maximum substrate solubility and the ethanol inhibition concentration. Therefore, the ethanol in the aqueous phase must be below the inhibitory concentration (approximately 18\% wt), and the substrate initial concentration must be below the solubility limit.

The idea of the addition of the solvent is to remove the most amount of ethanol and that the organic phase has a higher concentration of ethanol than the initial concentration, so that after the recovery of the solvent, the concentration of ethanol is higher. The objective of the extraction solvent is to obtain an organic phase 
with an ethanol concentration higher than that of the fermentation. Based on this, the chosen flow of solvent is $1 \mathrm{kmol} / \mathrm{h}$, which is a value that allows obtaining approximately an ethanol mole fraction of 0.26 and a flow of $0.65 \mathrm{kmol} / \mathrm{h}$, which is more than $60 \%$ of the ethanol produced in the fermentation.

\subsubsection{Distillation and rectification column}

The other two apparatuses chosen to be designed with topological thermodynamic analysis are the distillation and the rectification columns (both distillation columns). In terms of procedure, the application of thermodynamic-topological analysis is the same, but the specific components and concentrations of the columns differ from each other. The design variables to be determined for this equipment are: composition of the distillate and bottoms, flows of distillate and bottoms, profile composition inside the column and feed stage.

For the distillation column, which processes the aqueous phase that goes out of the decanter, the components with higher concentration are water, ethanol, dodecanol and glucose. The first element is the composition of the feed that enters into the column. The mole fraction of the feed is $0.93,0.069$ and 0.001 for water, ethanol and dodecanol, respectively. It can be observed that the composition of the feed is almost on the side of the triangle that represents a binary waterethanol mixture. Therefore, as dodecanol composition can be almost negligible, the two components that will be aimed to be purified are water and ethanol. In this case, the used number of stages is 20 , given that the typical values for distillation columns of ethanol are between 18-25 stages [37]. Finally, the last variable that can be determined is the feed stage, a decision that is based on the composition of the feed and the profile composition. This stage corresponds to the segment that crosses the point at which the feed is located, which in this case is the stage 13. This is all the topological thermodynamic analysis corresponding for the distillation column.

The following step is to perform the same strategy and analysis performed in the previous section for the distillation column, but now for the specific conditions and compositions of the rectification. For the rectification column, which processes the distillate of the distillation column mixed with the organic phase once the solvent is recovered, the components with higher concentration are water, ethanol and dodecanol. The mole fraction of the feed stream is $0.632,0.333$ and 0.035 for water, ethanol and dodecanol, respectively. The number of stages fixed was 30 given that the typical values for rectification columns of ethanol are between 25-30 stages [37]. Finally, the last variable that can be determined is the feed stage, which in this case is the stage 15 .

\subsection{Simulation procedure}

The simulation of the process was used to generate mass and energy balances, which are the main inputs to develop economic and environmental assessments. Table 3 shows the results obtained for the stipulated production capacity and the respective yield.

Table 3. Production capacity and yield of the production of ethanol using cocoyam as feedstock

\begin{tabular}{c|c|c|c|c}
\hline Tuber mass flow & \multicolumn{2}{|c|}{ Produced ethanol } & $\begin{array}{c}\text { Ethanol purity } \\
{[\% \text { mass] }}\end{array}$ & $\begin{array}{c}\text { Yield } \\
\text { [kg ethanol/kg tuber] }\end{array}$ \\
\hline $100 \mathrm{~kg} / \mathrm{h}$ & $7.059 \mathrm{~kg} / \mathrm{h}$ & $9.66 \mathrm{~L} / \mathrm{h}$ & 99.62 & 0.071 \\
\hline
\end{tabular}

Considering that this process is not currently analyzed using cocoyam as feedstock it was not possible to find data in the literature to compare the obtained yield. However, other starch feedstock as yucca obtained yields between 0.2 and 0.4 according to [21, 38, 39]. Compared to that value, the yield obtained in this study is lower, but this can be explained due to the fact that in such references the initial glucose concentration varies between 200-350 grams per liter, and in this study this value was approximately 120 grams per liter. In addition, this process does not intend to do any type of complementary concentration of the starch hydrolyzate, but to use as it was produced.

Furthermore, regarding another important aspect of the production process, the required crop area can be calculated based on the study performed by Gómez and Acero Duarte [4], where it is recommended that the spacing between plants must be of $1 \times 1$ meters hence giving a crop yield of approximately 10.000 plants per hectare. The results of the required area are shown in Table 4.

Table 4. Required crop area for the stipulated production capacity

\begin{tabular}{c|c|c|c|c}
\hline $\begin{array}{c}\text { Tuber mass flow } \\
{[\mathbf{k g} / \mathbf{h}]}\end{array}$ & $\begin{array}{c}\text { Required plants } \\
\text { [plants/h] }\end{array}$ & $\begin{array}{c}\text { Required plants } \\
\text { [plants/month] }\end{array}$ & $\begin{array}{c}\text { Planting rate } \\
\text { [plants/ha] }\end{array}$ & $\begin{array}{c}\text { Required area } \\
{[\mathbf{h a} / \mathbf{m o n t h}]}\end{array}$ \\
\hline 100 & 400 & 288000 & 10000 & 28.8 \\
\hline
\end{tabular}

The calculated value shows approximately 29 hectares per month, which represents an annual planted area about 320 hectares. As it was aforementioned, there are no technified cocoyam crops in Colombia. This value is considerably low compared to the planted area of yucca for industrial use, which exceed 12400 hectares [40]. Additionally, it is 
important to clarify that such planted area does not require to be simultaneously planted and grown at the same time, which lowers even more the required planted area.

\subsection{Economic assessment}

After the economic assessment of the process a sales price of 1.6 dollars per kilogram of the product was obtained. This price is higher than the actual commercial sales price of fuel ethanol which is 0.86 USD per kilogram [41]. This value can be explained due to the fact that this simulated process is in a preliminary stage. Hence, any level of integration has been applied (mass and energy integrations, among others), and those could diminish utilities and operation costs, which are the highest costs associated to this process, as it can be seen in Figure 6 .

The total capital cost of the project of 0.11 million dollars with 54 and 35 percent representing the operational and utilities costs, respectively. Utilities cost can be explained due to the use of distillation and rectification columns which have high energy demands both in the reboiler and the condenser that must be supplied by the selected utilities. Regarding operational cost, a considerable high amount of water is constantly being recirculated within the process for the pretreatment stage hence generating higher work demands to be supplied by the pumps.

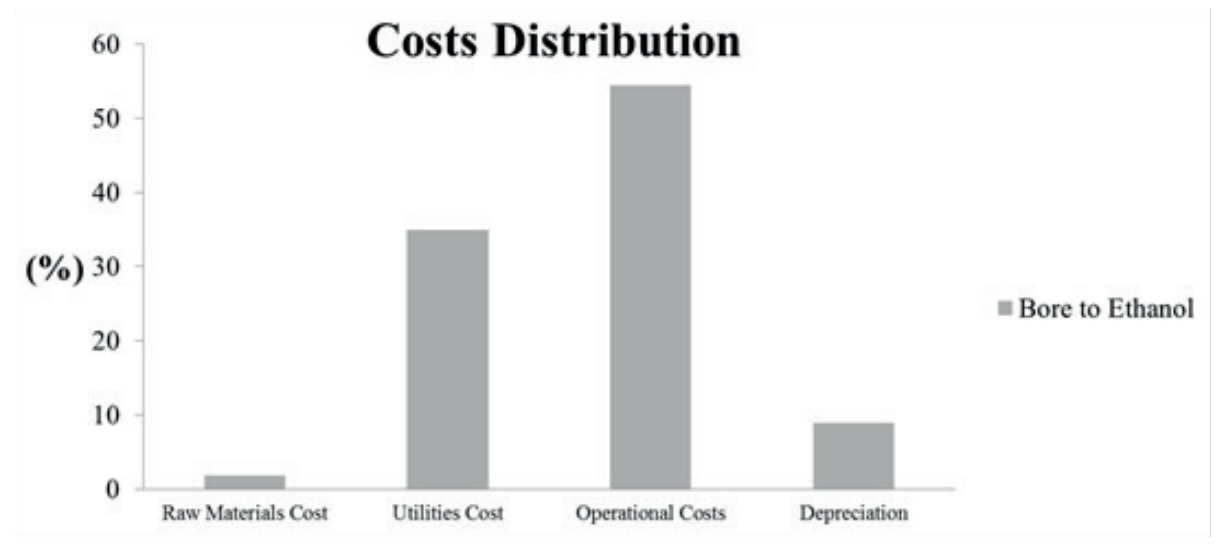

Fig. 6. Costs distribution of the ethanol production process.

\subsection{Environmental assessment}

Figure 7 presents the environmental assessment of the process. Eight impact categories are presented, among which the highest category that affects the environmental impact potential is the AP (acidification potential) and in a lower proportion the GWP (global warming potential). The rest of the categories can be considered as negligible. Both impacts can be explained due to the carbon dioxide that is generated in the fermentation and directly discharged on the atmosphere. Carbon dioxide is the primary greenhouse emitted through human activity and it warms the Earth by absorbing energy and slowing the rate at which the energy escapes to space; it acts as an insulating agent to the Earth [42]. Besides, this compound can also generate carbonic acid in the presence of water vapor which creates acid rain that acidifies both soil and water effluents.

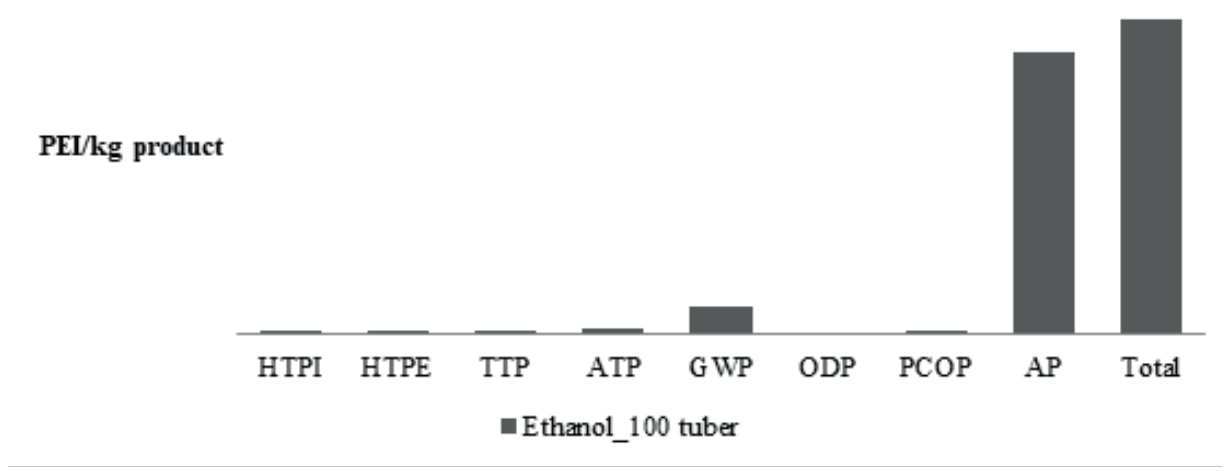

Fig. 7. Environmental impact potential of the eight evaluated categories for the production process $(\mathrm{PEI} / \mathrm{kg}$ product). 
However, it is important to mention that the total PEI is still a low value, implying that this process has not considerable environmental impacts.

\section{Conclusions}

The technical, economic and environmental preliminary analysis performed to the production process using cocoyam as feedstock demonstrated that this raw material has certain potential to be used as ethanol producing feedstock. It is necessary to perform further research in terms of the technification of the crop to consider other important variables such as production scale and crop costs. However, despite of the small difference of the calculated sales prices compared to the commercial sales price, the low environmental impact is an excellent incentive that shows that with further research this process can become a feasible alternative for the production of ethanol. Additionally, and even more important, this first-generation starchy raw material is not currently used neither for industrial

\section{References:}

1. Giacometti D., León J. La agricultura amazónica caribeña in Cultivos marginados: otra perspectiva de 1492 // Hernández J. E., León J., Ed. Food and Agriculture Organization of the United Nations Documents, 1992. P. 191-333. (in Span.).

2. Oke O. L. Roots, tubers, plantains and bananas in human nutrition // Redhead J., FAO Corporate Document Repository, 1998. 24 p.

3. Onwueme I. C., Charles W. B. Tropical Root and Tuber Crops: Production, Perspectives and Future Prospects // Ed. Food and Agriculture Organization of the United Nations Documents, 1994. 126 p.

4. Gómez M. Acero Duarte L. E., Guía para el cultivo y aprovechamiento del bore Alocasia macrorrhiza (Linneo) Schott // Ed. Convenio Andrés Bello, 2002. 43 p. (in Span.).

5. United States Department of Agriculture. Germplasm Resources Information Network (GRIN). // http://www.ars-grin.gov/cgi-bin/npgs/html/taxon. pl?42090.

6. United States Potato Board. Handbook of Potatoes Goodness // http://www.potatogoodness.com/ Content/pdf/PPNHandbook_Final.pdf.

7. Rojas Rivera M. A. Estudios de las características fisiológicasdelayuca//UndergraduateThesis.Universidad Tecnológica De Pereira // http://recursosbiblioteca.utp. edu.co/tesisd/textoyanexos/633682R741.pdf

8. Zhang C., Han W., Jing X., Pu G., Wang C. Life cycle economic analysis of fuel ethanol derived from cassava in southwest China // Renew. and Sustain. Energy Rev. 2003. V. 7. P. 353-366.

9. Quintero J., Montoya M. I., Sánchez O. J., applications nor as human food. Therefore, its use as raw material would not affect food security and presents a whole new opportunity for the production of biofuels. Furthermore, cocoyam can still be used for its current industrial use given that leaves remain intact from the production process, and the stem could be further analyzed to know its potential use, which will turn into an integral utilization of the plant. Regarding the design stage, thermodynamic-topological analysis proved to be a very useful tool that allows determining the most significant design variables of distillation and extractive fermentation processes with an easy-of-use graphical method.

\section{Acknowledgments}

The authors express their gratitude to the Universidad Nacional de Colombia Sede Manizales, the Research Group in Chemical, Catalytic and Biotechnological Processes, the "Jóvenes Investigadores" call No. 761 of Colciencias and the Institute of Fine Chemical Technologies (Moscow Technological University).

Giraldo O. H., Cardona C. Fuel ethanol production from sugarcane and corn: Comparative analysis for a Colombian case // Energy. 2008. V. 33. № 3. P. 385-399.

10. Jarboe L. R., Shanmugam K. T., Ingram L. O. Ethanol in Encyclopedia of Microbiology, Third // M. Schlaechter, Ed. Kidlington, Oxford, United Kingdom: Academic Press, 2009. P. 295-304.

11. Koizumi T. Biofuels and food security // Renew. and Sustain. Energy Rev. 2015. V. 52. P. 829-841.

12. Cardona C., Sánchez O. J., Gutiérrez Mosquera L. F. Process synthesis for fuel ethanol production // CRC Press, 2009. 415 p.

13. Quintero J. A., Moncada J., Cardona C. A. Techno-economic analysis of bioethanol production from lignocellulosic residues in Colombia: A process simulation approach // Bioresour. Technol. 2013. V. 139. P. 300-307.

14. Botero Londoño J. M. Valor nutricional de forrajes arbustivos para cerdas adultas / J. M. Botero Londoño // Master Thesis. Universidad Nacional de Colombia. 2004. // http://www.bdigital.unal.edu.co/6587/1/julianmauricio boterolondono.2004.pdf. (in Span.).

15. Zarate Higuera A., Gallo L. A., Jiménez Arango F. Aprovechamiento del bore (Alocasia macrorrhiza) en la alimentación de cerdos en etapa de ceba para reducir costos de producción // Rev. Innovando en la U. 2011. V. 3. P. 115-119. (in Span.).

16. López F., Caicedo A., Alegría G. Evaluación de tres dietas con harina de hoja de bore (Alocasia macrorrhiza) en pollos de engorde // Rev. MVZ Córdoba. 2012. V. 17. №. 3. P. 3236-3242. (in Span.).

17. Giacometti D., León J. Yautía o malanga (Xanthosoma sagittifolium) in Cultivos marginados: otra perspectiva de 1492 // Hernández J. E., León J., Ed. Food 
and Agriculture Organization of the United Nations Documents, 1992. P. 253-258. (in Span.).

18. Gómez M. E. Una revisión sobre el Bore (Alocasia macrorrhiza) in Agroforestería para la producción animal en América Latina-II // Ed. Food and Agriculture Organization of the United Nations Documents, 2003, P. 203-212. (in Span.).

19. Dubois M., Gilles K. A., Hamilton J. K., Rebers P. A., Smith F. Phenol sulphuric acid method for total carbohydrate // Anal. Chem. 1956. V. 26. 350 p.

20. Krishnaveni S., Sadavisam S., Balasubramanian T. Phenol sulphuric acid method for total carbohydrate // Food Chem. 1984. V. 15. 229 p.

21. Virunanon C., Ouephanit C., Burapatana V., Chulalaksananukul W. Cassava pulp enzymatic hydrolysis process as a preliminary step in bio-production from waste starchy resources // J. Clean. Prod. 2013. V. 39. P. 273-279.

22. Cardona C. A., Sánchez C. A., Gutiérrez L. F. Análisis de la Estática en Procesos de Destilación Reactiva in Destilación Reactiva: Análisis y Diseño Básico, First // Ed. Universidad Nacional de Colombia, 2007. 375 p. (in Spain.).

23. Forero Hernández H. A. Practical application of thermodynamics in the optimal synthesis of chemical and biotechnological processes / H. A. Forero Hernández // Master Thesis. Universidad Nacional de Colombia. 2015. // http://www.bdigital.unal.edu. co/50244/1/1053801196.2015.pdf.

24. Pisarenko Y. A., Danilov R., Yu R., Serafimov L. A. Study of modes for the reactive distillation analysis of statics // Theor. Found. Chem. Eng. 1995. V. 29. №. 6. P. 612-621.

25. Stanley D., Bandara A., Fraser S., Chambers P. J., Stanley G. A. The ethanol stress response and ethanol tolerance of Saccharomyces cerevisiae // J. Appl. Microbiol. 2010. V. 109. №. 1. P. 13-24.

26. Zhang Q., Wu D., Lin Y., Wang X., Kong H., Tanaka S. Substrate and product inhibition on yeast performance in ethanol fermentation // Energy and Fuels. 2015. V. 29. №. 2. P. 1019-1027.

27. Gutiérrez L. F., Sánchez Ó. J., Cardona C. A. Analysis and design of extractive fermentation processes using a novel short-cut method // Ind. Eng. Chem. Res. 2013. V. 52. №. 36. P. 12915-12926.

28. Taal M., Bulatov I., Klemeš J., Stehlík P. Cost estimation and energy price forecasts for economic evaluation of retrofit projects // Appl. Therm. Eng. 2003. V. 23. №. 14. P. 1819-1835.

29. Moncada J., El-Halwagi M. M., Cardona C. A. Techno-economic analysis for a sugarcane biorefinery: Colombian case // Bioresour. Technol. 2013. V. 135. P. 533-543.
30. Quintero J., Moncada J., Cardona C. Technoeconomic analysis of bioethanol production from lignocellulosic residues in Colombia: a process simulation approach // Bioresour. Technol. 2013. V. 139. P. 300-307.

31. Sassner P., Galbe M., Zacchi G. Technoeconomic evaluation of bioethanol production from three different lignocellulosic materials // Biomass and Bioenergy. 2008. V. 32. №. 5. P. 422-430.

32. Revista Nueva Mineria y Energía, "NME, N.m.y.E. LyD considers risky the proposal of an energetic development based on shale gas // http://www. nuevamineria.com/revista/2013. (in Span.).

33. Young D., Scharp R., Cabezas H. The waste reduction (WAR) algorithm: Environmental impacts, energy consumption, and engineering economics // Waste Manag. 2000. V. 20. №. 8. P. 605-615.

34. Cabezas H., Bare J. C., Mallick S. K. Pollution prevention with chemical process simulators: The generalized waste reduction (WAR) algorithm - Full version // Comput. Chem. Eng. 1999. V. 23. №. 4-5, P. 623-634.

35. Young D., Cabezas H. Designing sustainable processes with simulation: The waste reduction (WAR) algorithm // Comput. Chem. Eng. 1999. V. 23. №. 10. P. 1477-1491.

36. Cardona C., Marulanda V., Young D. Analysis of the environmental impact of butylacetate process through the WAR algorithm // Chem. Eng. Sci. 2004. V. 59. №. 24. P. 5839-5845.

37. Seader D., Henley E. J., Separation Process Principles, Second, V. 1 // Ed. John Wiley \& Sons, Inc. 2006. $821 \mathrm{p}$.

38. Esquivia M. B., Castaño H. I., Atehortua L., Acosta A., Mejía C. E. Producción de etanol a partir de yuca en condiciones de alta concentración de sólidos (VHG) // Rev. Colomb. Biotecnol. 2014. V. 16. №. 1. P. 1630 (in Span.).

39. Ingledew W. M. M., Lin Y. H., Ethanol from starch-based feedstocks in Comprehensive biotechnology, Second // Ed. Elsevier. 2011. P. 37-49.

40. Departamento Administrativo Nacional de Estadística (DANE). Censo de producción de yuca para uso industrial // https:/www.dane.gov.co/files/ investigaciones/agropecuario/enda/ena/Censo_plantas proces_yuca_uso_industrial2003.pdf.

41. Fedebiocombustibles, Precios de Biocombustibles en Colombia 2015. // http://www.fedebiocombustibles. com/estadistica-precios-titulo-Biodiesel.htm.

42. United States Environmental Protection Agency. Understanding Global Warming Potentials. // http://www3.epa.gov/climatechange/ghgemissions/ gwps.html. 


\section{About the authors:}

Sebastian Serna-Loaiza, Magister, Chair of Chemical Engineering, Institute of Biotechnology and Agroindustry, National University of Colombia (Instituto de Biotecnología y Agroindustria, Universidad Nacional de Colombia Sede Manizales, Km. 9 vía Aeropuerto La Nubia, Manizales-Caldas, Colombia 170001).E-mail: ssernal@unal.edu.co

Yuri A. Pisarenko, Dr.Sc. (Engineering), Professor of Chair of Basic Organic Synthesis, M.V. Lomonosov Institute of Fine Chemical Technologies, Moscow Technological University (86, Vernadskogo Pr., Moscow 119571, Russia). E-mail: pisarenko_yu@mail.ru

Carlos A. Cardona, Ph.D. (Engineering), Professor of Chair of Chemical Engineering, Institute of Biotechnology and Agroindustry, National University of Colombia (Instituto de Biotecnología y Agroindustria, Universidad Nacional de Colombia Sede Manizales, Km. 9 vía Aeropuerto La Nubia, Manizales-Caldas, Colombia 170001). E-mail: ccardonaal@unal.edu.co

\section{Об авторах:}

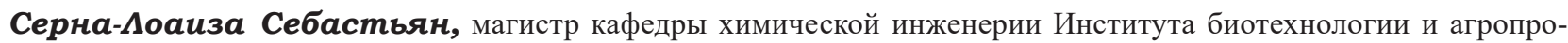
мышленности «Национальный университет Колумбии» (штаб-квартира Манизалес, Манизалес-Кальдас, Колумбия). E-mail: ssernal@unal.edu.co

Писаренко Юрий Андрианович, доктор технических наук, профессор кафедры основного органического синтеза Института тонких химических технологий имени М.В. Ломоносова ФГБОУ ВО «Московский технологический университет» (119571, Россия, Москва, пр-т Вернадского, д. 86). E-mail: pisarenko_yu@mail.ru

Кардона Карлос Ариэль, доктор философии, профессор кафедры химической инженерии Института биотехнологии и агропромышленности «Национальный университет Колумбии» (штаб-квартира Манизалес, Манизалес-Кальдас, Колумбия). E-mail: ccardonaal@unal.edu.co 